Volume 1 Nomor 1, Juli-Desember 2017: hlm. 55-64. Magister Ilmu Hukum, Fakultas Hukum, Universitas Lampung, Bandar Lampung, Lampung, Indonesia.

E-ISSN: 2598-3105 P-ISSN: 2723-2581

http://jurnal.fh.unila.ac.id/index.php/cepalo

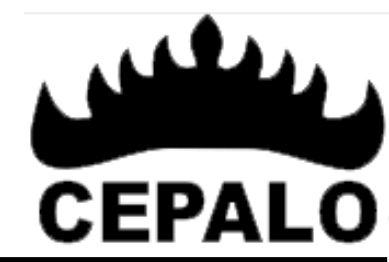

\title{
TANGGUNG GUGAT PERAWAT ASISTEN OPERATOR BEDAH DALAM MENJALANKAN PROFESINYA DI KAMAR OPERASI (STUDI DI RUMAH SAKIT UMUM DAERAH H.ABDUL MOELOEK PROVINSI LAMPUNG)
}

\section{THE RESPONSIBILITY OF A SURGICAL ASSISTANT NURSE IN CARRYING OUT THEIR PROFESSION IN THE OPERATING ROOM (STUDY AT THE H.ABDUL MOELOEK REGIONAL HOSPITAL IN LAMPUNG)}

\author{
Akhmad Sapri \\ Rumah Sakit Umum Daerah Dr.H. Abdul Moeloek \\ elsariasafira16@gmail.com
}

\begin{abstract}
Abstrak
Sebagaimana diketahui, tindakan perawat asisten operator bedah dilakukan sesuai dengan perintah dokter bedah, maka secara hukum tanggung jawabnya ada pada pemberi perintah. Selanjutnya, jika terjadi penyimpangan dari perintah maka sepenuhnya menjadi tanggung jawab perawat asisten operator bedah. Namun demikian, jika didapati terjadi kelalaian yang dilakukan oleh perawat maka apakah dokter turut bertanggung jawab atau rumah sakit tempat ia bekerja. Permasalahan dalam penelitian ini adalah bagaimana bentuk kewenangan dan bentuk tanggung gugat operator bedah, dan akibat hukum bila terjadi sengketa medis terhadap perawat asisten operator bedah dalam menjalankan profesinya di kamar operasi? Metode yang digunakan dalam penelitian ini adalah metode penelitian yuridis empiris dengan data primer hasil wawancara dan data sekunder dari buku serta literature.

Hasil penelitian menunjukkan bahwa bentuk kewenangan tenaga perawat asisten operator bedah dalam menjalankan profesinya di kamar operasi adalah melaksanakan tugas mandiri keperawatan, dan pelaksanaan tugas pelimpahan wewenang. Bentuk tanggung gugat perawat asisten operator bedah dalam menjalankan profesinya di kamar operasi rumah sakit merupakan tanggung jawab dokter. Akibat hukum bila terjadi sengketa medis terhadap perawat asisten operator bedah dalam menjalankan profesinya di kamar operasi dibebankan kepada rumah sakit atas segala terjadi atas kemudaratan akibat kelalaian yang diperbuat oleh dokter maupun perawat, sepanjang kelalaian tersebut tidak adanya faktor kesengajaan oleh tenaga kesehatan dan kejadian kesalahan tersebut dilakukan di rumah sakit bersangkutan.
\end{abstract}

Kata Kunci: Tanggung Gugat, Perawat Asisten Operator, Kamar Operasi

\begin{abstract}
The actions of the nurse's assistant surgical operator are carried out in accordance with the surgeon's orders, then the responsibility lies with the giver of the order. If there is a deviation from the order then it is entirely the responsibility of the assistant surgical operator nurse. However, if a nurse is found to be negligent, then is the doctor responsible or the hospital where the nurse works. The problem in this research is what is the form of authority and the form of accountability of the surgical operator, and the legal consequences if there is a medical dispute against the assistant surgical nurse in carrying out his profession in the operating room? The method used in this study is a juridical empirical research method with primary data from interviews and secondary data from books and literature. The results showed that the form of authority of the assistant surgical operator nurse in carrying out his profession
\end{abstract}


in the operating room was to carry out independent nursing duties, and the exercise of delegation of authority. The form of accountability of a nurse operating assistant nurse in carrying out her profession in a hospital operating room is the responsibility of the doctor. The legal consequences in the event of a medical dispute against the assistant surgeon in carrying out his profession in the operating room is charged to the hospital for any harm caused by negligence made by doctors or nurses, as long as such negligence is not a deliberate factor by health personnel and the error is committed at the hospital concerned.

\section{Keywords: Responsibility, Operator Assistant Nurse, Operating Room}

Cara Mengutip (How to Cite): Akhmad Sapri, “Tanggung Gugat Perawat Asisten Operator Bedah dalam Menjalankan Profesinya di Kamar Operasi (Studi di Rumah Sakit Umum Daerah H.Abdul Moeloek Provinsi Lampung)”, Jurnal Cepalo, 1 (1), (2017): 55-64.

DOI: https://doi.org/10.25041/cepalo.v1no1.1755

\section{A. Pendahuluan}

Rumah Sakit dan tenaga kesehatan adalah merupakan pihak-pihak yang memberikan pelayanan dalam bidang kesehatan. Sejalan daripada itu, Pasien adalah penerima pelayanan kesehatan oleh tenaga kesehatan tersebut. Implementasi ikatan antara tenaga kesehatan, rumah sakit dan pasien dikodifikasikan kedalam peraturan perundang-undangan dalam rangka menciptakan keteraturan dalam melaksanakan ikatan tersebut. Peraturan perundang-undangan ini biasanya di rancang sedemikian rupa sebagai pemenuh kebutuhan hukum rumah sakit tersebut.

Dilihat dari ikatan hukum antara dokter, tenaga kesehatan serta pasien, ikatan dokter, tenaga kesehatan serta ikatan pasien dan rumah sakit merupakan ikatan hukum untuk bersama-sama secara sepakat untuk mengikatkan diri sebagai pihak dalam perikatan (Verbentenis). Hal yang disebutkan di atas adalah termasuk dalam perikatan ikhtiar (inspanning verbentenis) yaitu termasuk dalam langkah-langkah dalam mengoptimalkan layanan kesehatan untuk para pasien. Tujuan paling hakiki atas diberlakukannya peraturan-peraturan adalah diciptakannya suatu kepastian hukum. ${ }^{1}$ Kepastian hukum ini meliputi segala upaya berdasarkan hukum untuk melindungi pasien dan perlindungan terhadap rumah sakit sebagai wadah berkerja bagi tenaga kesehatan. $^{2}$

Pengoptimalan pelayanan oleh rumah sakit sebagai pengampu dapat dilakukan apabila para dokter dan perawat serta pekerja administrasi rumah sakit dapat bekerja berdasarkan standar profesi, standar operasional serta standar tertentu dalam pelayanan rumah sakit (selanjutnya disingkat UU No. 25 Tahun 2009). Lebih jauh dijelaskan pada UU No. 25 Tahun 2009 yang mengatur tentang tanggung jawab hukum rumah sakit sebagai pelaksana layanan publik pada Pasal 15 diatur mengenai tujuan pelaksanaan pelayanan publik, diantaranya tercipta kepastian hukum serta perlindungan bagi masyarakat dalam bidang kesehatan.

Seperti diketahui, bahwa salah satu contoh layanan rumah sakit yang paling mengandung risiko adalah bidang pelayanan bedah. Hal ini seperti yang disampaikan oleh Suharjo Cahyono, bahwa bidang pelayanan bedah merupakan bagian pelayanan yang lebih sering menimbulkan cedera medis dan komplikasi dibandingkan di bagian lain. Misal, dalam tindakan pra bedah atau sebelum dilakukan operasi adalah tindakan anestesi, yang dalam tindakan ini pun selalu akan berisiko terhadap tubuh pasien. Seperti yang terjadi pada salah satu rumahsakit Karawaci Tanggerang, dijelaskan bahwa dua pasien meninggal dunia sesudah diberikan obat anastesi yang disebut Buvanet Spinal. ${ }^{3}$ Kasus ini menunjukkan begitu kompleksitasnya prosedur pra bedah di rumah sakit.

Pada prinsipnya pembedahan dalam dunia medik merupakan salah satu metode

\footnotetext{
${ }^{1}$ C.S.T Kansil dan Christine S.T Kansil, Pengantar Ilmu Hukum Indonesia, Yogyakarta: Cahaya Atma Pustaka, (2010), hlm. 43.

2 Titik Triwulan Tutik, Perlindungan Hukum Bagi Pasien, Jakarta: Prestasi Pustaka, (2010), hlm.

${ }^{3}$ Harian Kompas, tanggal 17 Februari 2015.
} 
penyembuhan penyakit (kuratif), terhadap seorang pasien, dengan kata lain tujuan pembedahan adalah untuk mengangkat atau menyembuhkan penyakit pasien, pasien tersebut ada indikasi medis yang memerlukan tindakan atau intervensi pembedahan. Dokter yang melakukan pembedahan terhadap pasien harus bekerja sesuai dengan prosedur dan dibantu oleh dokter anastesi, tanpa tindakan anastesi tidak akan mungkin dapat dilakukan proses pembedahan prosedur tersebut secara medis, oleh karena itu, dokter bedah secara prinsip tidak dapat dipisahkan dengan dokter anastesi. Selain itu dokter bedah dalam melakukan pembedahan di ruang operasi, selalu dibantu oleh perawat bedah yang lazim dalam dunia perumahsakitan disebut perawat asisten operator bedah. Tanpa perawat asisten operator bedah dokter tidak akan dapat bekerja secara maksimal, sehingga keberadaan perawat asisten operator bedah diruang operasi mutlak diperlukan.

Perawat asisten operator bedah pada prinsipnya bekerja atas perintah dokter bedah, oleh karena itu segala sesuatu tindakan perawat asisten operator bedah harus di ketahui oleh dokter bedah. Oleh karena itu tindakan perawat asisten operator bedah di kamar operasi, selain dilakukan sesuai dengan perintah dokter bedah, maka secara hukum tanggung jawabnya ada pada sipemberi perintah. Selanjutnya jika terjadi penyimpangan dari perintah yang diberikan oleh dokter maka sepenuhnya menjadi tanggung jawab perawat asisten operator bedah. Namun demikian apakah dokter harus menanggung seluruh akibat yang terjadi karena kelalaian perawat asisten operator bedahnya, dilihat dari tempat bekerjanya dokter, perawat apakah rumah sakit swasta atau pemerintah. Apakah tindakan yang dilakukan atas kelalaian itu dokter turut bertanggung jawab atau rumah sakit tempat ia bekerja. Sebagaimana tercantum didalam Undang-Undang nomor 44 tahun 2009 Pasal 46 tentang rumah sakit (selanjutnya disingkat UU No. 44 Tahun 2009) menentukan "Rumah sakit bertanggung jawab secara hukum terhadap semua kerugian yang ditimbulkan atas kelalaian yang dilakukan oleh tenaga kesehatan di rumah sakit". Maka dapat disimpulkan bahwa penyelenggara kesehatan (Rumah Sakit) mempunyai tanggung jawab hukum atas tenaga kesehatannya sehingga ada kejelasan dan ketegasan bagi masingmasing pihak. Oleh karenanya setiap pihak yang terkait, dapat dipertanggungjawabkan atas kesalahan dan kelalaian yang telah dilakukannya. Maka, kepastian hukum, keadilan hukum serta kemanfaatan hukum merupakan sebuah satu kesatuan tujuan hukum. ${ }^{4}$

Sebagai contoh dalam tindakan pelayanan medis berupa pembedahan selalu melibatkan beberapa tenaga medis dan tenaga kesehatan lainnya, dalam pembedahan yang dipimpin oleh dokter bedah selalu dibantu oleh asisten operator bedah yakni perawat bedah. Selain itu juga dibantu oleh tenaga medis yaitu dokter anasthesi, kedudukan perawat asisten operator bedah dalam kontek ini sangatlah penting karena perawat asisten operator bedah membantu setiap aktivitas dan kegiatan dalam hal pembedahan di ruang operasi. Dalam tugas bantuan tentu saja perawat asisten operator bedah mendapat perintah atau delegasi dari dokter bedah yang bersangkutan, sehingga masing-masing pihak baik dokter bedah maupun perawat asisten operator bedah mempunyai tanggung jawab masing-masing. Agar dalam hal ini tidak menimbulkan kekacauan atau ketidakteraturan siapa yang sebenarnya harus bertanggung jawab dalam kewajiban-kewajiban tertentu.

Sesuai dengan pemaparan diatas, dapat diteliti bagaimana tanggung gugat perawat asisten operator bedah dalam menjalankan profesinya di kamar operasi (Studi di Rumah Sakit Umum Daerah Dr. H Abdul Moeloek (RSUDAM) Provinsi Lampung, karena menurut pengamatan penulis RSUDAM merupakan rumah sakit Type B+ Pendidikan dan juga pusat rujukan tertinggi di provinsi Lampung, sedangkan IBS (Instalasi Bedah Sentral) RSUDAM memiliki 12 kamar operasi, 34 operator bedah dan 36 perawat asisten operator bedah, 10 dokter anastesi dan di bantu oleh 18 perawat anastesi, tindakan operasi rata-rata perhari 20 pasien. Dalam pelayanan bedah, operator bedah selalu sebagai dokter penanggung jawab pelayanan (DPJP), sementara perawat merupakan asisten operator sedangkan pekerjaan tersebut dilakukan oleh tim yang terdiri dari operator bedah, asisten operatornya perawat, dan dokter anastesi. Tidak adil dan tidak logis rasanya bila tanggung jawab hukumnya selalu dibebankan kepada rumah sakit sementara petugas lainnya di ruang operasi juga menikmati hasilnya berupa uang jasa

\footnotetext{
${ }^{4}$ Sudikno Martokusumo, Mengenal Hukum: Suatu Pengantar, Yogyakarta: Liberty, (1999), hlm. 24.
} 
pelayanan.

Maka sesuai dengan pemaparan diatas dapat dilihat yang akan di bahas dalam tulisan ini yakni terkait wujud kewenangan tenaga perawat asisten operator bedah dalam menjalankan profesinya di kamar operasi, bentuk tanggung gugat perawat asisten operator bedah dalam menjalankan profesinya di kamar operasi, serta mencari tahu akibat hukum bila terjadi sengketa medis terhadap perawat asisten operator bedah dalam menjalankan profesinya di kamar operasi. Permasalahan dalam penelitian ini adalah bagaimana bentuk kewenangan dan bentuk tanggung gugat operator bedah, dan akibat hukum bila terjadi sengketa medis terhadap perawat asisten operator bedah dalam menjalankan profesinya di kamar operasi? Metode yang digunakan dalam penelitian ini adalah metode penelitian yuridis empiris dengan data primer hasil wawancara dan data sekunder dari buku serta literature.

\section{B. Pembahasan}

1. Bentuk Kewenangan Tenaga Perawat Asisten Operator Bedah Dalam Menjalankan Profesinya di Kamar Operasi

Di negara Anglo Saxon terdapat dokrin yang dikenal dengan borrowed servand (tenaga kesehatan pinjaman), dalam hal pelaksananannya, harus ditentukan terlebih dahulu apakah tenaga-tenaga tersebut adalah tenaga terdidik sesuai dengan pendidikan dan profesinya yang nantinya kewenangannya berada dibawah pengawasan dokter. Apabila terbukti demikian, untuk dapat dinyatakan bahwa tenaga kesehatan tersebut adalah borrowed servand, maka tenagatenanga kesehatan itu dalam hal ini adalah Perawat yang dipinjamkan kepada dokter sebagai akibat dari perjanjian terkait tetap harus dididik atas perintah dokter. ${ }^{5}$ Bentuk modifikasi hubungan hukum yang diterbitkan sebagai akibat adanya toelatings contract adalah bahwa oleh dokter tamu di rumah sakit swasta dalam melakukan tindakan operasi terhadap seorang pasien memerlukan tim dengan macam-macam jenis latar belakang skills yang terdiri dari operator bedah dan ahli anestesi. Tim tersebut biasanya adalah tim tunggal yang dipimpin oleh dokter bedah selaku operator dan berlaku sebagai ketua tim begitu pula dengan dokter anastesi. Namun demikian, dapat pula dibuat lebih dari satu tim operator, tim pertama terdiri dari ahli bedah, juga asisten bedah dan perawat dan tim yang lain bisa tim anestesi yang terdiri dari ahli anestesi dan asisten anestesi. Yang tiap tiap tim mempunyai ketua sebagai captain of the ship.

Penerapan toelatingscontract pada sebuah rumah sakit, pada dasarnya merupakan merupakan bentuk dan jenis kontrak yang tumbuh dan berkembang dalam praktik pada pelayanan kesehatan. Perkembangan kontrak innominaat dalam bentuk toelatingscontract merupakan konsekuensi dari sistem terbuka (open system) dari Kitab Undang-Undang Hukum Perdata pada Pasal 1338 ayat (1) berbunyi "Semua perjanjian yang dibuat secara sah berlaku sebagai undang- undang bagi mereka yang membuatnya". Disini jelas dinyatakan bahwa setiap pihak bebas untuk melakukan perjanjian dalam hal apapun, sudah ataupun belum pernah diatur dalam peraturan. Namun demikian kebebasan dalam hal pembuatan perjanjian atau kontrak diatur oleh undang-undang, ketertiban umum serta kesusilaan.

Hasil wawancara dengan operator bedah mengatakan bahwa, tugas utama perawat asisten operator bedah adalah memperlancar proses operasi dan tanggung jawab dalam pelaksanaan operasi adalah tanggung jawab operator bedah. Kalaupun ada tindakan yang didelegasikan, tetap menjadi tanggung jawab operator dan instruksi yang didelegasikan sepengengetahuan dan dalam pengawasan operator. Dalam pendelegasian wewenang, operator mempertimbangkan kemampuan asisten operator dan kepercayaan terhadap asisten operator. ${ }^{6}$

Hasil wawancara dengan asisten operator mengatakan, bentuk kewenangan perawat asisten operator dalam pelaksanaan tugas sesuai dengan SOP. Semua jenis pelayanan di ruang kamar operasi sudah ada SOP nya. Pelaksanaannya mengikuti SOP. Dalam pelaksanaan tugas delegasi, pelaksanaannya sudah pasti sepengetahuan dan pengawasan operator. ${ }^{7}$

\footnotetext{
${ }^{5}$ Indra Sari Aulia, "Tanggung Jawab Hukum Rumah Sakit terhadap Kelalaian Medis yang Dilakukan Tenaga Kesehatan", Tesis Magister Hukum Unila, (2014), hlm. 63.

${ }^{6}$ Wawancara dengan dr. Marzuki, Sp.Obg dalam, Operator Bedah, di Ruang Bedah pada RSUD. Dr.H. Abdul Moeloek Provinsi Lampung, Senin, 25 Juni 2018.

${ }^{7}$ Wawancara dengan Ns. Rafludin Muchlisin, Perawat Asisten Operator Bedah di Ruang Bedah pada RSUD. Dr. H.
} 
Hasil wawancara dengan direktur Pelayanan RSUD Dr. H. Abdul Moeloek adalah semua jenis pelayanan dirumah sakit bersangkutan telah diatur dalam SOP, semua jenis tindakan operasi tanggung jawab penuh ada pada dokter DPJP nya, perawat asisten operator bedah dan penata anastesi adalah membantu proses pelayanan dan kelancaran tindakan bedah di rumah sakit. $^{8}$

Hasil wawancara dengan komite medik adalah Ada dua jenis pelimpahan wewenang yaitu secara delegatif dan mandat. Pelimpahan wewenang delegatif dilimpahkan kepada perawat sesuai profesi yang mempunyai kompetensi yang dibutuhkan disertai tanggung jawabnya oleh para tenaga kesehatan, sedangkan pelimpahan wewenang mandat dilimpahkan kepada perawat dalam rangkaian kegiatan medis yang mana kewenangan ini diawasi dan dipertanggungja wabkan oleh pemberi wewenang. ${ }^{9}$

Berdasarkan uraian diatas bentuk kewenangan perawat asisten operator yang ada di kamar bedah rumah sakit adalah melaksanakan tugas mandiri keperawatan sebagai mana diuraikan di atas, tugas utama perawat asisten operator bedah adalah memperlancar proses operasi dan tanggung jawab dalam pelaksanaan operasi adalah tanggung jawab operator bedah kalaupun ada tindakan yang didelegasikan tetap tanggung jawabnya pada operator, instruksi yang didelegasikan sepengengetahuan dan dalam pengawasan operator. Dalam pendelegasian wewenang, operator mempertimbangkan kemampuan asisten operator dan kepercayaan terhadap asisten operator. Pelimpahan wewenang delegatif yang desertai pelimpahan tanggung jawab pula hanya bisa dilimpahkan pada perawat vokasi yang terlatih atau perawat profesi yang mempunyai skill yang dibutuhkan. sedangkan pelimpahan wewenang mandat dilimpahkan kepada perawat dalam rangkaian kegiatan medis yang mana kewenangan ini diawasi dan dipertanggungjawabkan oleh pemberi wewenang. Hal ini sudah ditentukan pada UU No. 38 Tahun 2014 Pasal 29, terkait tugas perawat dan Pasal 32 tentang pemberian wewenang, sebagaimana yang telah dijelaskan diatas.

Dalam melaksanakan tugas mandiri keperawatan, dan pelaksanaan tugas pelimpahan wewenang perawat bekerja sesuai dengan SOP yang telah di buat oleh rumah sakit. Dalam hal ini menurut pengamatan penulis perawat yang bekerja pada Rumah Sakit Umum Daerah H. Abdoel Moeloek Provinsi Lampung sudah bekerja berdasarkan SOP yang ada, dari semua tindakan perawatan mulai dari persiapan, pelaksanaan, dan sesudah operasi. Segala macam jasa kesehatan yang disedikan telah diatur dalaam Standar Operasional Prosedur (SOP). Dan SOP sendiri telah diatur dalam ketentuan UU No. 29 Tahun 2009 Pasal 50 ialah "Suatu perangkat instruksi atau langkah-langkah yang dibakukan untuk menyelesaikan suatu proses kerja rutin tertentu". Standar Operasional Prosedur (SOP) dirancang atas kesepakatan bersama yang juga dalam perancangannya didasari oleh standar profesi untuk mencapai fungsi rumah sakit sebagai pelaksana pelayanan publik. Semua jenis tindakan operasi tanggung jawab penuh ada pada dokter DPJP nya, perawat asisten operator bedah dan penata anastesi adalah membantu proses pelayanan dan kelancaran tindakan bedah di rumah sakit. Perawat dalam menjalankan praktiknya harus terikat pada kewajiban etis, yaitu: Memuliakan martabat pasien. Dan bahwa setiap masyarakat wajib dilayani sebagai insan yang mempunyai hak dasar termasuk hak dalam memilih nasib dirinya.Berbuat baik (beneficence). Segala tindakan perawat harus terarah pada tujuan memulihkan kesehatan pasien, dan senantiasa mengutamakan kesehatan penderita, tidak merugikan pasien (non-maleficence). Sebelum tindakan keperawatan, perawat harus memahami keuntungan dan kerugian masing-masing pilihan tersebut. Bersikap adil (justice). Dalam menjalankan tugasnya perawat tidak membedakan status sosial, ekonomi, agama, pendidikan, selain kepentingan kesehatan pasien yang merupakan perhatian utama perawat.

\section{Bentuk Tanggung Gugat Perawat Asisten Operator Bedah Dalam Menjalankan}

\footnotetext{
Abdul Moeloek Provinsi Lampung, Senin, 25 Juni 2018.

${ }^{8}$ Wawancara dengan dr. Pad Dilangga, Sp. P. Direktur Pelayanan pada RSUD. Dr. H. Abdul Moeloek Provinsi Lampung, Kamis, 28 Juni 2018.

${ }^{9}$ Wawancara dengan dr. Taufiqur Rahman, Sp. Obgin, K. Ketua Komite Medis pada RSUD. Dr. H. Abdul Moeloek Provinsi Lampung, Senin, 2 Juli 2018.
} 


\section{Profesinya di Kamar Operasi}

Didalam hukum diketahui terdapat dua jenis perjanjian perikatan, ialah: ${ }^{10}$

a. Resultaatsverbintenis, perjanjian yang berlandaskan dari hasil pekerjaannya.

b. Inspanningverbintenis, perjanjian yang berlandaskan dari sebuah usaha.

Secara Umum, dalam menjalankan tugasnya, dokter sebagai pemberi mandat kepada para perawatnya, harus siap bertanggung jawab atas resiko kesalahan yang mungkin dilakukan para perawatnya. Dalam hal kesembuhan pasien, dokter hanyalah pihak penolong agar pasien dapat sembuh, bukan pihak yang dapat menjamin kesembuhan pasien.

Pada umumnya di sebuah rumah sakit Pemerintah, tenaga keperawatan merupakan pegawai tetap yang berstatus sebagai Pegawai Negeri Sipil (PNS), sehingga secara administrasi juga berlaku undang-undang kepegawaian. Para tenaga keperawatan tersebut merupakan tenaga profesional di rumah sakit yang melayani pasien. Tenaga keperawatan di sini adalah tenaga tetap atau sebagai sub- ordinate dari rumah sakit atau sebagai pegawai rumah sakit. Dalam konteks sebagai pegawai, tenaga keperawatan harus melaksanakan kewajiban penyelenggara kesehatan pada masyarakat dalam bidang kesehatan. Dengan ini maka penyelenggara kesehtan tersebut dianggap sebagai principal dan tenaga keperawatan sebagai agent, Dan pasien sebagai pemberi kontraprestasi. Oleh karena itu hubungan seperti ini pada umumnya berlaku pada rumah sakit pemerintah dimana para perawatnya diupah secara konsisten dan full.

Melalui hubungan rumah sakit dan tenaga keperawatan seperti di atas, maka apabila terjadi kerugian yang harus ditanggung oleh pasien sebagai akibat dari kelalaian perawat, maka rumah sakit sebagai wadah bekerja mereka adalah pihak yang dibebani tanggung jawab. Hasil wawancara dengan bagian hukum Rumah Sakit Umum Daerah Abdoel Moeloek ialah bila terjadi insiden terhadap perawat asisten operator bedah, rumah sakit turut bertanggung jawab secara perdata, dalam telaah kasus karyawannya semua diurai satu persatu baik secara pidana, perdata, dan administrasi dari tanggung jawab masing-masing namun secara institusi rumah sakit turut bertanggung jawab secara perdata berdasarkan UU No. 44 Tahun 2009. Kalau untuk kasus pidana merupakan tanggung jawab individu itu sendiri tergantung siapa yang melakukan kesalahan tersebut. ${ }^{11}$

Dari uraian di atas dapat dipastikan bahwa bentuk tanggung gugat perawat asisten operator bedah dalam menjalankan profesinya di kamar operasi rumah sakit merupakan tanggung jawab dokter. Bila terjadi insiden terhadap perawat asisten operator bedah, rumah sakit turut bertanggung jawab secara perdata. Dalam telaah kasus karyawannya semua diurai satu persatu baik secara pidana, perdata, dan administrasi dari tanggung jawab masing-masing namun secara institusi rumah sakit turut bertanggung jawab secara perdata berdasarkan UU No. 44 Tahun 2009. Sedangkan dalam kasus pidana, merupakan tanggung jawab individu itu sendiri tergantung siapa yang melakukan kesalahan tersebut. Dalam hal ini, dokter memegang tanggung jawab penuh atas kesalahan dari tindakan medis perawat yang dibawahinya, sedangkan jika perawat tersebut melakukan kelalaian yang berakibat kerugian pasien, maka dalam hal ini rumah sakit sebagai wadah mereka bekerja adalah pihak yang dibebani tanggung jawab, sepanjang tidak adanya faktor kesengajaan tenaga kesehatan yang menimbulkan kerugian. Malpraktik pidana karena kesengajaan (intensional), ditanggung oleh tenaga kesehatan itu sendiri. Misalnya, Dalam kasus pembocoran rahasia kedokteran, keterlambatan pertolongan medis pada pasien gawat darurat, praktik aborsi tanpa indikasi medis, dan dalam skala lebih kecil yaitu pemberian surat dokter illegal. ${ }^{12}$

Mereka ini, perawat dan dokter yang bekerja di Rumah Sakit Umum Daerah Abdoel Moeloek Provinsi Lampung sebagai ASN terikat pada peraturan-peraturan dan disiplin ASN serta peraturan dari pihak rumah sakit. Lalu Pernyataan dari Guwandi menyebutkan, dokterdokter ini biasanya dikenal dengan sebutan dokter organic. ${ }^{13}$ Dalam hal ini dikenal dengan

\footnotetext{
${ }^{10}$ Fred Ameln, Kapita selekta Hukum Kedokteran, Jakarta: Grafikatama Jaya, (1991), hlm. 42.

${ }^{11}$ Wawancara dengan Drs. Anindito, Apt, MM. Kabag Hukum Dan Perlindungan SDM pada RSUD. Dr. H. Abdul Moeloek Provinsi Lampung, Senin, 25 Juni 2018.

12 Anny Isfandyarie, Malpraktik dan Risiko Medik (Dalam Kajian Hukum Pidana), Jakarta: Prestasi Pustaka Publisher, (2005). hlm. 34-35.

${ }^{13} \mathrm{~J}$ Guwandi, Informed Consent and Informed Refusal, Jakarta: Fakultas Kedokteran Universitas Indonesia, (2006),
} 
doktrin majikan dan karyawan. Maksudnya rumah sakit sebagai wadah bekerja para tenaga medis dan perawat sebagai karyawan yang bekerja dirumah sakit, maka apabila terjadi kerugian akibat kesalahan karyawannya, rumah sakit akan dibebankan tanggung jawab hukum untuk mengganti kerugian. Dalam hal membantu dokter, maka hal yang sama berlaku. Bahwa dokter adalah pihak yang dibebani tanggung jawab hukum akibat kesalahan perawat yang dibawahinya. Namun, perlu dibedakan apabila tuntutan tersebut adalah tuntutan pidana, maka pertanggungjawaban hukum bersifat pribadi sesuai dengan jenis kesalahan atau kelalaian yang diperbuat. Didalam ketentuan Pasal 1367 KUHPdt dijelaskan secara tepat mengenai pekerjaan perawat sebagai karyawan dirumah sakit yang berbunyi: "Seorang tidak saja bertanggung jawab untuk kerugian yang disebabkan karena penbuatannya sendiri, tetapi juga untuk kerugian yang disebabkan karena perbuatan orang-orang yang menjadi tanggungannya". Berlandaskan hal tersebut dapat disimpulkan bahwa perawat rumah sakit tidaak bertanggung jawab atas kesalahannya karena ia bekerja atau menjalankan jasa pelayanan kesehatan atas instruksi dari tempat ia bekerja (rumah sakit), yang selanjutnya pula dijelaskan dalam UU Nomor 44 Tahun 2006 pada Pasal 46 menetapkan "Rumah sakit bertanggung jawab secara hukum terhadap semua kerugian yang ditimbulkan atas kelalaian yang dilakukan oleh tenaga kesehatan di rumah sakit".

Secara umum, ikatan antara dokter, perawat, rumah sakit dan pasien adalah suatu hubungan ikhtiar. Maksudnya tenaga medis yang dalam hal ini adalah dokter dan perawat tidak dapat menjamin kesembuhan pasiennya namun berikhtiar dengan harapan dan keyakinan supaya pasiennya dappat sembuh, hubungan ini disebut dengan Inspanningverbintenis. Sedangkan tanggung jawab hukum antara dokter dan perawat adalah merupakan "keterikatan" seorang dokter sebagai pemberi mandat berdasarkan ketentuan hukum. Tanggung jawab dokter dan perawat dibidang hukum, khususnya hukum perdata adalah sebagai berikut:

\section{a. Tanggung Jawab Hukum Akibat Wanprestasi}

Wanprestasi sendiri memiliki definisi sebagai suatu peristiwa dimana satu pihak secara sadar tidak melakukan pemenuhan atas kewajiban yang telah dituangkan ke dalam suatu perjanjian. Dalam hukum perdata, suatu pihak dapat dinyatakan telah melakukan wanprestasi jika; Tidak memenuhi kewajiban dengan tidak melaksanakan apa yang telah disepakati untuk dilaksanakan, atau melaksanakan apa yang telah disepakati namun tidak sesuai, serta melakukan hal yang telah dituangkan didalam perjanjian untuk tidak dilakukan.

\section{b. Tanggung Jawab Tenaga Kesehatan Akibat Perbuatan Melawan Hukum (onrechtmatige daad)}

Perbuatan melawan hukum merupakan tindakan yang ditetapkan oleh undang- undang sebagai pelanggaran karena adanya unsur merugikan hak lain, bertentangan dengan hukum, melanggar norma etis seperti adat istiadat masuarakat, tidak sejalan dengan kepatutan seseorang dalam hidup bermasyarakat.

\section{c. Akibat Hukum Bila Terjadi Sengketa Medis Terhadap Perawat Asisten Operator Bedah dalam Menjalankan Profesinya Di Kamar Operasi}

Dalam praktik, jenis kesalahan dokter yang merugikan pasien lebih dikenal dengan istilah malpraktik. Junus Hanafiah memberi batasan bahwa Malpraktik medik merupakan kesalahan baik itu sengaja ataupun tidak sengaja, berupa kelalaian yang dilakukan oleh tenaga medis dalam mengobati pasien menggunakan keahlian dan ilmu pendidikan yang dimilikinya. ${ }^{14}$ Dalam ranah medis para ahli telah setuju bahwa yang disebut malpraktik merupakan kelalaian dokter yang menyebabkan kecacatan pada pasien atau bahkan meninggal dunia karena ia tidak menggunakan ilmu pendidikan dan keahliannya berdasarkan standar profesi yang telah

hlm. 87.

14 Junus Hanafiah dan Amri Amir, Etika kedokteran dan Hukum Kesehatan, Jakarta: Buku Kedokteran EGC, (2003), hlm.87. 
ditetapkan. ${ }^{15}$ Berikut ini merupakan 3 syarat yang harus dilakukan dokter dalam tindakam medis supaya tidak dinyatakan sebagai malpraktik, antara lain:

1) Indikasi Medis terarah kepada tujuan pelayanan kesehatan secara konkret

2) Pelayanan Kesehatan dilaksanakan berdasarkan peraturan yang berlaku.

3) Sudah disetujui oleh pasien sebelumnya.

Didalam KODEKI dituangkan aturan-aturan memgenai standar etis, aturan atau norma, dan prinsip prinsip berprilaku para dokter. Terkait dengan malpraktik, dikenal ada dua jenis malpraktik, pertama malpraktik secara etik (ecthical mallpractice) dan malpraktik secara yuridis (yuridicial malpractiice). Malpraktik etik berkaitan langsung dengan etika dokter yang terdapat pada KODEKI, malpraktik ini misalnya pada bidang diagnostik, terkadang pemeriksaan lebih lanjut kepada pasien oleh dokter di laboraturium tidak terlalu dibutuhkan, tetapi karena adanya kesepakatan bahwa dokter akan diberikan hadiah atau uang maka dokter mengirim pasiennya kesana, padahal pemeriksaan laboraturium sebenarnya tidak dibutuhkan untuk itu. Lebih jauh daripada itu, malpraktik etik pula ditemukan dalam bidang terapi, misalnya dalam kasus sebuah perusahaan farmasi yang menawarkan jenis obat antibiotik kepada dokter dengan iming-iming tertentu apabila dokter bersedia memakai antibiotik itu. Karena terkadang hal itu juga bisa berpengaruh terhadap pengambilan keputusan dokter dalam memberi terapi ke pasiennya. Pelaksanaan terapi yang berdasar dari janji perusahaan farmasi yang justru tidak sesuai dengan indikasi yang dibutuhkan pasien. Pada prinsipnya tanggung jawab rumah sakit secara limitatif telah ditetapkan dalam ketentuan UU Nomor 44 Tahun 2009 pada Pasal 46, menentukan bahwa "Rumah sakit bertanggung jawab secara hukum terhadap semua kerugian yang ditimbulkan atas kelalaian yang dilakukan oleh tenaga kesehatan di rumah sakit".

Hasil wawancara dengan bagian hukum Rumah Sakit Umum Daerah Abdoel Moeloek Provinsi Lampung adalah bila perawat asisten operator bedah melakukan pekerjaan sesuai dengan perintah operator, maka tanggung jawabnya ada pada operator bedah. Tapi sebaliknya, jika perawat asisten operator bedah melakukan tindakan diluar perintah operator atau tidak sesuai dengan SOP dan merugikan pasien maka yang bertanggung jawab adalah perawat asisten operator itu sendiri. Selain itu, rumah sakit juga ikut bertanggung jawab secara perdata berdasarkan ketentuan UU Nomor 44 Tahun $2009 .{ }^{16}$ Dari uraian di atas dapat dijelaskan akibat hukum bila terjadi sengketa medis terhadap perawat asisten operator bedah dalam menjalankan profesinya di kamar operasi rumah sakit yang membuat pihak rumah sakit memiliki tanggung jawaab hukum untuk mengganti kerugian yang terjadi sebagai akibat kelalaian para tenaga medis atas tindakannya terhadap pasien. Sepanjang kelalaian tersebut tidak adanya kesengajaan oleh tenaga kesehatan dan kejadian kesalahan tersebut dilakukan di rumah sakit bersangkutan. bila perawat asisten operator bedah melakukan pekerjaan sesuai dengan perintah operator, maka tanggung jawabnya ada pada operator bedah. Tapi sebaliknya, jika perawat asisten operator bedah melakukan tindakan diluar perintah operator atau tidak sesuai dengan SPO dan merugikan pasien maka yang bertanggung jawab adalah perawat asisten operator itu sendiri. Selain itu, rumah sakit juga ikut bertanggung jawab secara perdata berdasarkan ketentuan UU Nomor 44 Tahun 2009 pada Pasal 29 yang menentukan bahwa sengketa akibat kelalaian yang dilakukan perawat atau tenaga medis lain harus dimediasi terlebih dahulu.

Untuk kesalahan dan kelalaian yang dilakukan perawat harus diurai satu persatu. Oleh karena itu, perlu di garisbawahi apabila kelalaian tersebut berupa kesengajaan para tenaga medis, maka rumah sakit tidak bisa dituntut, karena kelalaian murni dilakukan secara sengaja oleh karyawannya. Syarat-syarat untuk dapat dikategorikan perbuatan melawan hukum, maka malpraktik keperawatan ini jelas-jelas merupakan perbuatan melawan hukum (baik tertulis maupun hukum tak tertulis), maka dapat disimpulkan bahwa malpraktik harus dilakukan atas dasar kesalahan, yang karenanya menimbulkan kerugian dan mempunyai hubungan kausal antara perbuatan dan kerugian tersebut. Namun demikian, menjalankan tugas sebagai perawat, keterikatan terhadap norma etika saja tidaklah mencukupi. Oleh karena itu, perawat juga

\footnotetext{
${ }^{15}$ Anny Isfandyarie, Tanggungjawab Hukum dan Sanksi Bagi Dokter, Jakarta: Prestasi Pustaka, (2008), hlm. 22.

${ }^{16}$ Wawancara dengan Drs. Anindito, Apt, MM. Kabag. Hukum Dan Perlindungan SDM pada RSUD. Dr. H. Abdul Moeloek Provinsi Lampung, Senin, 25 Juni 2018.
} 
dituntut untuk bekerja sesuai peraturan yang berlaku sebagai hukum positif dalam pelayanan keperawatan.

Pengambilan keputusan klinis dalam praktik kedokteran mengacu pada konsep Evidence Based Medicine (EBM). EBM merupakan suatu konsep yang disusun sebagai bagian dari proses untuk menjamin tercapainya efektivitas klinis pelayanan kesehatan penderita. Kenyataan tersebut sebenarnya telah tercermin dalam sifat perikatan tenaga kesehatan dan pasiennya yg harus memberikan jasa kesehatan berdasarkan usaha maksimal yang sebaik-baiknya (inspannings verbitenis), bukan berdasarkan hasil (resultaatverbintenis) seperti pada perikatan di luar hubungan dokter dan pasien. Sebenarnya apabila dokter dalam melayani pasien bersifat patient-centered health care (pasien menjadi prioritas utama dalam pelayanan klinis), maka kemungkinan kecil akan terjadi tindakan defensive medicine. Prinsip ini merupakan cara mempertahankan diri seorang dokter dalam menghindari tuntutan dari pasien. Dokter berusaha untuk menghindari atau merujuk pasien yang berisiko atau melakukan tes diagnostil secara berkelebihan.

Berdasarkan uraian di atas menurut pengamatan penulis, dalam praktik pelayanan medis dapat terjadi adanya sengketa medis karena pengaruh kultur ilmiah dan perkembangan kedokteran modern yang menyebabkan ancaman keselamatan berupa cedera akibat tindakan medis. Hal ini terjadi sebagai akibat penggunaan teknologi yang tidak sesuai dengan kebutuhan pasien. Oleh karena itu tindakan-tindakan medis mulai dari diagnosis, pembedahan, pemeriksaan lanjutan di laboraturium, serta dalam hal obat-obatan yang diberikan wajib berdasarkan oleh ketentuan yang ada, hal ini dilakukan untuk meminimalisir terjadinya kerugian pasien atau keluarga pasoen dalam persoalan fisik ataupun finansial. Dalam kaitan ini, menimbulkan dampak yang merugikan bagi pasien (kejadian yang tidak diharapkan akibat tindakan medis).

\section{Penutup}

Bentuk tanggung gugat perawat asisten operator bedah dalam menjalankan profesinya di kamar operasi merupakan tanggung jawab ketua tim yang dalam hal ini adalah dokter ketua, dikarenakan kesalahan timbul karena perawat sedang melakukan arahan dokter. Sejalan dengan kasus dimana perawat melakukan kelalaian yang menimbulkan kerugian pasien, maka rumah sakit sebagai wadah ia bekerja adalah pihak yang dibebani tanggung jawab, sepanjang tidak adanya faktor kesengajaan tenaga kesehatan yang menimbulkan kerugian. Sedangkan dalam kasus pidana merupakan tanggung jawab individu itu sendiri tergantung siapa yang melakukan kesalahan tersebut. Bentuk tanggung jawab hukum tenaga kesehatan yakni dokter, dan tanggunggung gugat perawat merupakan "Keterikatan" tenaga kesehatan terkait pelaksanaan profesinya yang dalam hal ini dokter harus mematuhi ketentuan- ketentuan hukum mengenai Tanggung jawab seorang dokter dan Perawat.

Akibat hukum bila terjadi sengketa medis terhadap perawat asisten operator bedah dalam menjalankan profesinya di kamar operasi rumah sakit, dapat dipastikan bahwa sesuai hukum, rumah sakit adalah pihak yang dibebani tanggung jawab untuk menhganti segala jenis kerugian yang diderita pasien akibat kesalahan para tenaga medik pada rumah sakit itu sepanjang kelalaian tersebut tidak adanya kesengajaan oleh tenaga kesehatan dan kejadian kesalahan tersebut dilakukan di rumah sakit bersangkutan, bila perawat asisten operator bedah melakukan pekerjaan sesuai dengan perintah operator, maka tanggung jawabnya ada pada operator bedah, tapi sebaliknya jika perawat asisten operator bedah melakukan tindakan diluar perintah operator atau tidak sesuai dengan SPO dan merugikan pasien maka yang bertanggung jawab adalah perawat asisten operator itu sendiri, selain itu rumah sakit juga ikut bertanggung jawab secara perdata berdasarkan ketentuan UU Nomor 44 Tahun 2009 pada Pasal 2929 yang menentukan bahwa sengketa akibat kelalaian yang dilakukan perawat atau tenaga medis lain harus dimediasi terlebih dahulu.

\section{A. Buku}

\section{DAFTAR PUSTAKA}


Ameln, Fred. (1991). Kapita selekta Hukum Kedokteran. Jakarta: Grafikatama Jaya.

C.S.T Kansil dan Christine S.T Kansil. (2010). Pengantar Ilmu Hukum Indonesia. Yogyakarta: Cahaya Atma Pustaka.

Hanafiah, Junus dan Amri Amir. 2003. Etika kedokteran dan Hukum Kesehatan. Jakarta: Buku Kedokteran EGC.

Isfandyarie, Anny. (2005). Malpraktik dan Risiko Medik (Dalam Kajian Hukum Pidana). Jakarta: Prestasi Pustaka Publisher.

Isfandyarie, Anny. (2008). Tanggungjawab Hukum dan Sanksi Bagi Dokter. Jakarta: Prestasi Pustaka.

J. Guwandi. (2006). Informed Consent and Informed Refusal. Jakarta: Fakultas Kedokteran Universitas Indonesia.

Martokusumo, Sudikno. (1999). Mengenal Hukum: Suatu Pengantar. Yogyakarta: Liberty.

Tutik, Titik Triwulan. (2010). Perlindungan Hukum Bagi Pasien. Jakarta: Prestasi Pustaka.

\section{B. Sumber Lain}

Aulia, Indra Sari. 2014. Tanggung Jawab Hukum Rumah Sakit terhadap Kelalaian Medis yangDilakukan Tenaga Kesehatan. Tesis Magister Hukum Unila. Bandar Lampung: Universitas Lampung. 